\title{
NSD3 wt Allele
}

National Cancer Institute

\section{Source}

National Cancer Institute. NSD3 wt Allele. NCI Thesaurus. Code C96342.

Human NSD3 wild-type allele is located in the vicinity of 8p11.23 and is approximately 113 $\mathrm{kb}$ in length. This allele, which encodes histone-lysine N-methyltransferase NSD3 protein, plays a role in the regulation of histone methylation. A chromosomal translocation $\mathrm{t}(8 ; 11)$ (p11;p15) involving the NUP98 gene and this gene is associated with acute myeloid leukemia. 